\title{
BAURAN PEMASARAN JASA TERHADAP KEPUASAN PASIEN RAWAT JALAN REHABILITASI MEDIK FISIOTERAPI RUMAH SAKIT UNDATA PALU
}

\author{
MICHAEL PEONI \\ ELIMAWATY ROMBE \\ BENYAMIN PARUBAK \\ Program Studi S1 Manajemen Fakultas Ekonomi Universitas Tadulako \\ Email: michaelpeoni@gmail.com
}

\begin{abstract}
This study aims to find out information related to outpatient services Rehabilitation of Physiotherapy in Undata Palu Hospital. The variables in this research are product (X1), price (X2), place (X3), promotion (X4), person (X5), physical evidence (X6) and process (X7). While the dependent variable is patient satisfaction $(Y)$. This type of research is quantitative. The method of this research is descriptive causal. The sample used in this research is as much as 98 respondents with the form of sampling using purposive sampling technique. Data analysis used in this research is multiple linier regression analysis method. The results of this study indicate that simultaneously a mix of services consisting of products, places, promotions, people, evidence and a significant process to patient satisfaction outpatient medical rehabilitation hospital Undata Palu. And partially there is no relationship between product variables, price, promotion, people and facts with patient satisfaction, while the relationship variable and patient satisfaction.
\end{abstract}

Keywords: service marketing mix, Patient satisfaction.

Abstrak
Penelitian ini bertujuan untuk mengetahui pengaruh bauran pemasaran jasa terhadap kepuasan pasien rawat jalan rehabilitasi medik fisioterapi rumah sakit Undata Palu. Variabel independen yang digunakan dalam penelitian ini adalah produk $\left(\mathrm{X}_{1}\right)$, harga $\left(\mathrm{X}_{2}\right)$, tempat $\left(\mathrm{X}_{3}\right)$, promosi $\left(\mathrm{X}_{4}\right)$, orang $\left(\mathrm{X}_{5}\right)$, bukti fisik $\left(\mathrm{X}_{6}\right)$ dan proses $\left(\mathrm{X}_{7}\right)$. Sedangkan variabel dependen adalah kepuasan pasien $(\mathrm{Y})$. Jenis penelitian ini adalah kuantitatif. Metode penelitian ini adalah deskriptif kausal. Sampel yang digunakan pada penelitian ini yaitu sebanyak 98 responden dengan bentuk pengambilan sampel menggunakan teknik purposive sampling. Metode analisis data yang digunakan dalam penelitian ini adalah metode analisis regresi linear berganda. Hasil penelitian ini menunjukkan bahwa secara serempak bauran pemasaran jasa yang terdiri dari produk, harga, tempat, promosi, orang, bukti fisisk dan proses berpengaruh signifikan terhadap kepuasan pasien rawat jalan rehabilitasi medik rumah sakit Undata Palu. Secara parsial tidak ada hubungan antara variabel produk, harga, promosi, orang dan bukti fisik dengan kepuasan pasien, sedangkan adanya hubungan variabel tempat, proses dengan kepuasan pasien.

Kata kunci: bauran pemasaran jasa, Kepuasan pasien.

\section{PENDAHULUAN}

Pelayanan jasa dalam bidang kesehatan sangat bergantung pada tingkat kunjungan pasien. Peningkatan tersebut memicu timbulnya persaingan antar rumah sakit. Pihak rumah sakit dituntut untuk lebih bekerja keras dan kreatif lagi dalam menarik para pasien yakni dengan mengembangkan strategi pemasaran. Pelayananan rehabilitasi medik cukup di butuhkan oleh beberapa orang yang mengalami masalah dari sistem saraf dan tulang. Produk dan jasa yang diberikan kepada pasien rehabilitasi medik membantu dalam penyembuhan dan mengembalikan fungsi sistem saraf agar berfungsi secara optimal

Pelayanan fisioterapi merupakan bagian dari rehabilitasi Medik dalam mengupayakan peningkatan kualitas kesehatan dengan cara pencegahan, penyembuhan dan pemulihan gangguan sistem gerak dan fungsi. Fisioterapi merupakan ilmu yang menitikberatkan untuk menstabilkan atau memperbaiki 
Peoni, M.

gangguan fungsi alat gerak/fungsi tubuh yang terganggu yang kemudian diikuti dengan proses/metode terapi gerak.

\section{KAJIAN LITERATURE DAN PENGEMBAGAN HIPOTESIS}

\section{Pengertian Bauran Pemasaran jasa}

Tjiptono (2014:41) menyatakan bauran pemasaran merupakan seperangkat alat yang dapat digunakan pemasar untuk membentuk karakteristik jasa yang ditawarkan kepada pelanggan. Alat-alat tersebut dapat digunakan untuk menyusun strategi jangka panjang dan merancang program taktik jangka pendek.

\section{Konsep Bauran Pemasaran Jasa}

Rosida (2010:81) menyatakan bauran pemasaran (Marketing Mix) merupakan variabel-variabel terkendali (controllable) yang dapat digunakan untuk mempengaruhi tanggapan konsumen dari segmen pasar tertentu yang dituju untuk membentuk karakteristik jasa yang ditawarkan kepada pelanggan.

a. Produk

Rosida (2010:83) menyatakan produk merupakan elemen utama dalam pemasaran dan produk ini yang akan ditawarkan kepada pelanggan. Produk adalah barang atau jasa yang dapat diperjual belikan. Di dalam marketing, produk adalah apapun yang bisa ditawarkan ke sebuah pasar dan bisa memuaskan sebuah keinginan atau kebutuhan.

b. Harga

harga adalah sejumlah uang yang di bebankan atas suatu produk atau jasa, atau jumlah dari nilai yang di tukar konsumen atas manfaat-manfaat karena memiliki atau menggunakan produk atau jasa tersebut. Sehingga dapat disimpulkan bahwa harga adalah suatu nilai yang mencakup semua pengorbanan yang di gunakan sebagai alat tukar untuk mendapatkan, memiliki dan menggunakan barang atau jasa. (Rosida, 2010:85)

c. Promosi

Promosi adalah bagian dari kegiatan pemasaran yang bertujuan untuk meningkatkan penjualan produk atau layanan Promosi berisi informasi untuk pelanggan potensial dan yang sudah ada. Promosi dapat digunakan untuk membujuk pelanggan potensial dan yang sudah ada untuk membeli kembali produk atau layanan (Zahara dan Rombe,2017)

d. Tempat

Tempat adalah berhubungan dengan lokasi dimana rumah sakit tesebut melakukan operasional jasanya. Menurut Kamus Besar Bahasa Indoesia (KBBI) "Sesuatu yang dipakai untuk menaruh (menyimpan, meletakkan, dan sebagainya). Menurut Rosida (2010:86) tempat merupakan gabungan antara lokasi dan keputusan atas saluran distribusi, dalam hal ini berhubungan dengan bagaimana cara penyampaian jasa pelanggan dan dari mana lokasi yang strategis

e. Orang

Rosida (2010:90) menyatakan people adalah peranan manusia dalam memainkan suatu bagian dalam penyampaian layanannya yang mempengaruhi persepsi pembeli, yaitu karyawan perusahaan, pelanggan, dan pelanggan lain dalam lingkup pelayanan

f. Bukti Fisik

Bukti Fisik merupakan suatu hal yang mempengaruhi kepuasan konsumen untuk membeli dan menggunakan barang atau jasa yang ditawarkan.Tjiptono (2014:43) menyatakan karakteristik intangible pada jasa menyebabkan pelanggan potensial tidak bisa menilai suatu jasa sebelum mengkonsumsinya. Ini menyebabkan risiko yang dipersepsikan konsumen dalam keputusan pembelian semakin besar. 


\section{g. Proses}

Proses adalah urutan pelaksanaan atau kejadian yang saling terkait yang bersama-sama mengubah masukan menjadi keluaran Rosida (2010:91) menyatakan proses adalah prosedur nyata, mekanisme dan serangkaian aktifitas dalam penyampaian layanan. Proses adalah semua prosedur aktual, mekanisme dan aliran aktivitas dengan jasa mana yang disampaikan serta merupakan sistem penyajian atau operasi jasa.

\section{Pengertian Kepuasan Pasien}

Pasien/masyarakat melihat layanan kesehatan yang bermutu sebagai suatu layanan kesehatan yang dapat memenuhi kebutuhan yang dirasakan dan diselenggarakan dengan cara yang sopan dan santun, tepat waktu, tanggap serta mampu menyembuhkan keluhan serta mencegah berkembangnya atau meluasnya penyakit. Pandangan pasien ini sangat penting karena pasien yang merasa puas akan mematuhi pengobatan dan mau datang berobat kembali.

\section{Kerangka Pemikiran}

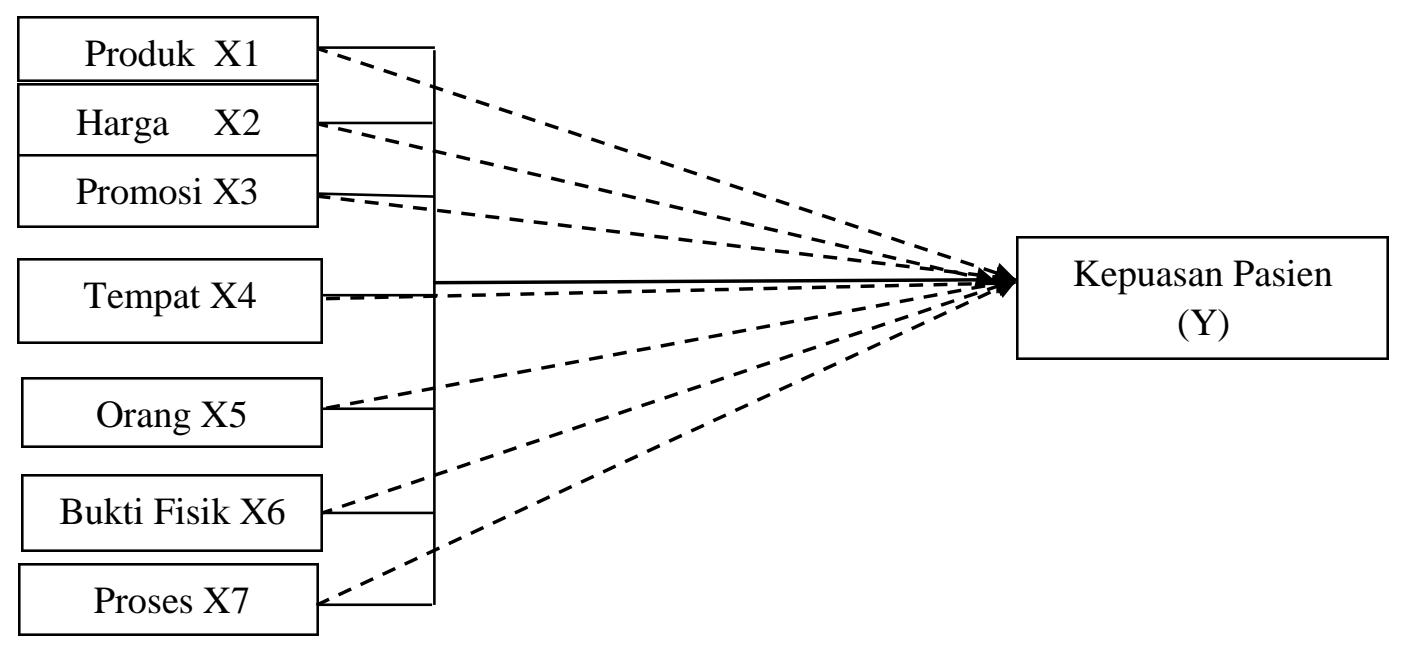

\section{Gambar 1. Kerangka Pemikiran}

Keterangan:

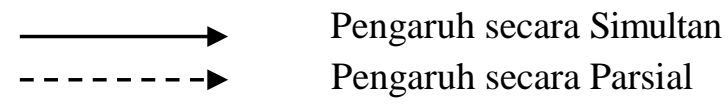

\section{Hipotesis}

Hipotesis penelitian adalah dugaan sementara mengenai dua variabel atau lebih mengenai hasil penelitian, selanjutnya hipotesis penelitian ini dirumuskan sebagai berikut:

a. Bauran pemasaran jasa berpengaruh signifikan terhadap kepuasan pasien rehabilitasi medik Undata Palu

b. Produk berpengaruh signifikan terhadap keputusan konsumen kepuasan pasien rehabilitasi medik Rumah sakit Undata Palu

c. Harga berpengaruh signifikan terhadap kepuasan pasien rehabilitasi medik Rumah sakit Undata Palu

d. Tempat berpengaruh signifikan terhadap kepuasan pasien rehabilitasi medik Rumah sakit Undata Palu 
Peoni, M.

e. Promosi berpengaruh signifikan terhadap kepuasan pasien rehabilitasi medik Rumah sakit Undata Palu

f. Orang berpengaruh signifikan terhadap kepuasan pasien rehabilitasi medik Rumah sakit Undata Palu

g. Bukti Fisik berpengaruh signifikan terhadap kepuasan pasien rehabilitasi medik Rumah sakit Undata Palu

h. Proses berpengaruh signifikan terhadap kepuasan pasien rehabilitasi medik Rumah sakit Undata Palu

\section{METODE PENELITIAN}

Jenis penelitian yang digunakan adalah deskriptif-kausal dan desain penelitian ini adalah deskriptif kausal, oleh karena penelitian ini berusaha menjabarkan hasil-hasil penelitian dari pengaruh variabel independen (X), yaitu produk, harga, tempat, promosi, orang, bukti fisik, dan proses terhadap variabel (Y), yaitu kepuasan pasien rawat jalan di rehabilitasi medik fisioterapi rumah sakit Undata Palu.

Penelitian deskriptif adalah penelitian yang dilakukan untuk mengetahui nilai variabel mandiri, baik satu variabel atau lebih (independen) tanpa membuat perbandingan atau menghubungkan antara variabel satu dengan variabel yang lain. Populasi adalah wilayah generalisasi yang terdiri atas obyek/subyek yang mempunyai kualitas dan karakteristik tertentu yang di tetapkan oleh peneliti untuk dipelajari dan kemudian ditarik kesimpulannya. Jadi populasi bukan hanya orang, tetapi juga obyek dan benda-benda alam yang lain. Populasi juga bukan sekedar jumlah yang ada pada obyek/subyek yang dipelajari, tetapi meliputi seluruh karakteristik/sifat yang dimiliki oleh subyek atau obyek tertentu (sugiyono, 2014:115). Populasi dalam penelitian ini adalah semua pasien rawat jalan yang pernah menggunakan jasa rehabilitasi medik di Rumah Sakit Undata Palu. Metode pengambilan sampel yang digunakan dalam penelitian ini adalah probability Sampling dan menggunakan teknik puposive sampling yaitu teknik penentuan sampel berdasarkan pertimbangan tertentu, yaitu sampel responden yang dipilih adalah responden yang sudah pernah menggunakan jasa rehabilitasi medik di Rumah Sakit Undata Palu. kriteria responden yang dijadikan sampel pada penelitian ini agar dipandang cocok sebagai sumber data adalah sebagai berikut:

a) Semua pasien yang pernah menggunakan layanan jasa rehabilitasi medik fisioterapi RS Undata Palu.

b) Pasien yang pernah menggukanan layanan fisioterapi lebih dari 2 kali.

jumlah pasien yang sudah menggunakan layanan jasa rehabilitasi medik fisioterapi RS Undata Palu selama tahun 2017 sebanyak 5.360 pasien. Berdasarkan jumlah populasi untuk ditentukan ukuran sampel dengan menggunakan rumus Slovin sebagai berikut:

$$
n=\frac{N}{1+N(e)^{2}}
$$

Keterangan:

$\mathrm{n}=$ Sampel

$\mathrm{N}=$ Populasi

$\mathrm{e}=$ Persen kelonggaran / ketidaktelitian karena kesalahan pengembalian sampel yang dapat di tolerir / diinginkan.

Menggunakan tingkat kesalahan (e) sebesar 10\% maka formulasi yang dikemukakan Slovin akan digunakan pada penelitian ini guna menentukan besar sampel: 


$\begin{aligned} \mathrm{n} & =\frac{5.360}{1+5.360(0,1)^{2}} \\ & =\frac{5.360}{54.6} \\ & =98 \text { responden }\end{aligned}$

\section{Pengujian Instrumen Penelitian}

Sebelum data dikumpulkan dan diolah, maka peneliti perlu melakukan uji coba instrumen terlebih dahulu guna mengetahui tingkat validitas dan reliabilitas suatu instrumen.

\section{Uji Validitas}

Uji validitas digunakan untuk mengukur sah atau valid tidaknya suatu kuesioner, suatu kuesioner dikatakan valid jika pertanyaan pada kuesioner mampu untuk mengungkapkan sesuatu yang akan diukur oleh kuesioner tersebut. Syarat minimum untuk dianggap memenuhi syarat adalah $r=0.3$. Jadi, korelasi antara butir dengan skor total kurang dari 0.3 maka butir dalam instrument tersebut dinyatakan tidak valid. Sebaliknya, bila skor total sama dengan 0.3 atau lebih (paling kecil 0.3) maka instrumen tersebut dinyatakan valid, (Sugiyono 2014:188).

\section{Uji Reliabilitas}

Sunyoto (2013:81) uji reliabilitas adalah alat untuk mengukur suatu kuesioner yang merupakan indikator dari variabel atau konstruk. Butir pertanyaan dikatakan reliabel atau handal apabila jawaban seseorang terhadap pertanyaan adalah konsisten. Suatu konstruk atau variabel dikatakan reliabel jika memberikan nilai Cronbach Alpha $>0.60$.

\section{Metode Analisis}

\section{Uji Nomalitas}

Uji Normallitas digunakan untuk menguji apakah dalam sebuah model regresi variabel (pengganggu) dependen dan independen atau keduanya memiliki distribusi normal (Ghozali 2013:160). Model regresi yang baik adalah distribusi data normal atau mendekati normal. Deteksi normalitas dilakukan dengan melihat penyebaran data (titik) pada sumbu diagonal dan grafik

\section{Uji Multikolinearitas}

Uji Multikolineeritas digunakan untuk menguji apakah model regresi ditemukan adanya kolerasi antara variabel bebas independen. Model regresi yang baik seharusnya antara variabel independen tidak terjadi korelasi antara variabel independen (Ghozali, 2013:105). Uji multikolinearitas dapat dilakukan dengan melihat nilai VIF (Variance Inflation Factors). Jika tolerance $\leq 0.10$ atau sama dengan nilai VIF maka menunjukan adanya multikolinieritas.

\section{Uji Heteroskedastisitas}

Ghozali (2013:139) menyatakan uji heteroskedastisitas yaitu untuk menguji apakah dalam model regresi terjadi ketidaksamaan variance dari residual satu pengamatan ke pengamatan yang lain. Jika variance dari residual satu pengamatan ke pengamatan lain tetap, maka disebut homoskedastisitas dan jika berbeda disebut heteroskedastisitas Model regresi yang baik adalah tidak terjadi heteroskedastisitas

\section{Analisis regresi Linier Berganda}

Analisis regresi linier berganda adalah hubungan secara linear antara dua atau lebih variabel independen $\left(\mathrm{X}_{1}, \mathrm{X} 2, \ldots \ldots \mathrm{Xn}\right)$ dengan variabel depedenden $(\mathrm{Y})$. Analisis regresi linier berganda digunakan untuk mengetahui ada tidaknya pengaruh produk, harga, tempat, promosi, orang, bukti fisik, dan proses terhadap kepuasan pasien rehabilitasi medik Rumah sakit Undata Palu, maka digunakan alat uji statistik yaitu regresi linear berganda yang dapat dirumuskan (Sugiyono, 2014: 262): 
Peoni, M.

$$
\mathrm{Y}=\mathrm{a}+\mathrm{b} 1 \mathrm{X} 1+\mathrm{b} 2 \mathrm{X2}+\mathrm{b3} \mathrm{X3}+\mathrm{b} 4 \mathrm{X} 4+\mathrm{b5} \mathrm{X} 5+\mathrm{b} 6 \mathrm{X6}+\mathrm{b} 7 \mathrm{X} 7+\mathrm{e}
$$

Keterangan:

$\mathrm{Y}=$ Kepuasan Pasien

$\mathrm{a}=$ Konstanta

b1, b2, b3, b4, b5, b6, b7 = Koefisien regresi masing-masing variabel

$\mathrm{X} 1=$ Produk $($ Product $)$

$\mathrm{X} 2$ = Harga $($ Price $)$

$\mathrm{X} 3=$ Tempat (Place)

$\mathrm{X} 4=$ Promosi (Promotion)

$\mathrm{X} 5=$ Orang $($ People)

X6 $=$ Bukti Fisik (Physical Evidence)

$\mathrm{X} 7=$ Proses (Process)

$\mathrm{e}=$ error $/$ variabel pengganggu

\section{HASIL DAN PEMBAHASAN}

\section{Hasil Uji Validitas dan Reliabilitas}

Berikut ini adalah hasil uji validitas dan reliabilitas atas item pertanyaan yang terdapat dalam kuesioner penelitian terhadap variabel produk $\left(\mathrm{X}_{1}\right)$, harga $\left(\mathrm{X}_{2}\right)$, promosi $(\mathrm{X} 3)$, tempat (X4), Orang(X5), bukti fisik(X6), Proses(X7). dan kepuasan pasien (Y). Adapun hasilnya disajikan dalam tabel 1 berikut:

Tabel 1. Validitas dan Reliabilitas Instrumen Penelitian

\begin{tabular}{|c|c|c|c|c|c|}
\hline Variabel & Item & $\begin{array}{c}\text { Total } \\
\text { Correlation }\end{array}$ & Ket & $\begin{array}{c}\text { Cronbach } \\
\text { Alpha }\end{array}$ & Ket \\
\hline \multirow{3}{*}{ produk $\left(\mathrm{X}_{1}\right)$} & $\mathrm{X} 1.1$ & 0,754 & Valid & \multirow{3}{*}{0,871} & \multirow{3}{*}{ reliabel } \\
\hline & $\mathrm{X} 1.2$ & 0,792 & Valid & & \\
\hline & $\mathrm{X} 1.3$ & 0,759 & Valid & & \\
\hline \multirow{3}{*}{$\operatorname{harga}\left(X_{2}\right)$} & $\mathrm{X} 2.1$ & 0,652 & Valid & \multirow{3}{*}{0,782} & \multirow{3}{*}{ reliabel } \\
\hline & $\mathrm{X} 2.2$ & 0,762 & Valid & & \\
\hline & $\mathrm{X} 2.3$ & 0,532 & Valid & & \\
\hline \multirow{3}{*}{$\operatorname{promosi}(\mathrm{X} 3)$} & X3.1 & 0,346 & Valid & \multirow{3}{*}{0,703} & \multirow{3}{*}{ reliabel } \\
\hline & X3.2 & 0,701 & Valid & & \\
\hline & X3.3 & 0,625 & Valid & & \\
\hline \multirow{3}{*}{ tempat (X4) } & $\mathrm{X} 4.1$ & 0,445 & Valid & \multirow{3}{*}{0,681} & \multirow{3}{*}{ reliabel } \\
\hline & $\mathrm{X} 4.2$ & 0,677 & Valid & & \\
\hline & $\mathrm{X} 4.3$ & 0,425 & Valid & & \\
\hline \multirow{3}{*}{ Orang(X5) } & X5.1 & 0,906 & Valid & \multirow{3}{*}{0,911} & \multirow{3}{*}{ reliabel } \\
\hline & X5.2 & 0,842 & Valid & & \\
\hline & X5.3 & 0,730 & Valid & & \\
\hline \multirow{3}{*}{ bukti fisik(X6) } & X6.1 & 0,720 & Valid & \multirow{3}{*}{0,815} & \multirow{3}{*}{ reliabel } \\
\hline & X6.2 & 0,716 & Valid & & \\
\hline & X6.3 & 0,673 & Valid & & \\
\hline \multirow{3}{*}{ Proses $(X 7)$} & X7.1 & 0,675 & Valid & \multirow{3}{*}{0,884} & \multirow{3}{*}{ reliabel } \\
\hline & X7.2 & 0,827 & Valid & & \\
\hline & X7.3 & 0,847 & Valid & & \\
\hline
\end{tabular}


ISSN : 2443-3578 (On Line)/ ISSN : 2443-1850 (Print)

\begin{tabular}{|c|c|c|c|c|c|}
\hline Variabel & Item & $\begin{array}{c}\text { Total } \\
\text { Correlation }\end{array}$ & Ket & $\begin{array}{c}\text { Cronbach } \\
\text { Alpha }\end{array}$ & Ket \\
\hline kepuasan pasien (Y) & $\begin{array}{l}\text { Y1 } \\
\text { Y2 } \\
\text { Y3 }\end{array}$ & $\begin{array}{l}0,774 \\
0,848 \\
0,693\end{array}$ & $\begin{array}{l}\text { Valid } \\
\text { Valid } \\
\text { Valid }\end{array}$ & 0,858 & reliabel \\
\hline
\end{tabular}

\section{Sumber: Data diolah Tahun 2018}

Berdasarkan hasil uji validitas dan reliabilitas diperoleh bahwa seluruh variabel memiliki koefisien Cronbach Alpha (a) lebih besar dari 0,60 sehingga berdasarkan syarat minimum reliabilitas lebih besar dari 0,60 maka seluruh variabel yang digunakan reliabel dan dapat digunakan dalam penelitian ini. Sedangkan uji validitas terhadap seluruh variabel juga menunjukan nilai koefisien korelasi yang lebih besar dari 0,30 sehingga item pernyataan yang ada valid untuk digunakan.

\section{Hasil Uji Analisis Regresi Linear Berganda}

Penelitian ini menggunakan analisis regresi linear berganda dengan tujuan untuk menguji variabel bauran pemsararan jasa terhadap kepuasan pasien rawat jalan rehabilitasi medik fisioterapi Rumah Sakit Undata. Untuk lebih jelasnya hasil analisis regresi linear berganda dapat dilihat pada tabel 2 berikut:

Tabel 2. Hasil Uji Analisis Regresi Linear Berganda

\begin{tabular}{|c|c|c|c|c|c|}
\hline \multicolumn{6}{|c|}{ Dependen Variabel $Y$ = Kepuasan Pasien } \\
\hline \multirow{2}{*}{$\begin{array}{c}\text { Variabel } \\
\text { Independen }\end{array}$} & \multicolumn{2}{|c|}{$\begin{array}{c}\text { Unstandardized } \\
\text { Coefficients }\end{array}$} & \multirow{2}{*}{$\begin{array}{c}\text { Standardized } \\
\text { Coefficients }\end{array}$} & \multirow[t]{2}{*}{$\mathrm{t}$} & \multirow[t]{2}{*}{ sig } \\
\hline & B & Std. Error & & & \\
\hline (Constant) & 0,400 & 0,365 & & 1,094 & 0,277 \\
\hline produk $\left(\mathrm{X}_{1}\right)$ & $-0,20$ & 0,078 & $-0,028$ & $-0,255$ & 0,799 \\
\hline $\operatorname{harga}\left(\mathrm{X}_{2}\right)$ & 0,107 & 0,075 & 0,107 & 1,427 & 0,157 \\
\hline promosi (X3) & $-0,091$ & 0,079 & $-0,121$ & $-1,151$ & 0,253 \\
\hline tempat $(\mathrm{X} 4)$ & 0,243 & 0,089 & 0,336 & 2,723 & 0,008 \\
\hline Orang(X5) & 0,159 & 0,101 & 0,143 & 1,570 & 0,120 \\
\hline bukti fisik(X6) & $-0,043$ & 0,054 & $-0,078$ & $-0,673$ & 0,503 \\
\hline Proses(X7) & 0,541 & 0,090 & 0,571 & 5,992 & 0,000 \\
\hline Multiple R & $=0,779^{\mathrm{a}}$ & \multicolumn{4}{|l|}{ Sig. $F=0,000$} \\
\hline Adjusted R Square & $=0,577 \alpha$ & \multicolumn{4}{|c|}{$=0,05$ tingkat kepercayaan $95 \%$} \\
\hline
\end{tabular}

Berdasarkan tabel 2 di atas, dapat di tulis dalam bentuk persamaan regresi linear berganda. Lebih jelasnya bentuk persamaan tersebut dapat dilihat sebagai berikut:

$$
\mathrm{Y}=\mathrm{a}+\mathrm{b} 1 \mathrm{X1}+\mathrm{b} 2 \mathrm{X2}+\mathrm{b3} \mathrm{X3}+\mathrm{b4} \mathrm{X} 4+\mathrm{b5} \mathrm{X5}+\mathrm{b} 6 \mathrm{X6}+\mathrm{b} 7 \mathrm{X7}+\mathrm{e}
$$

1. Koefisien regresi variabel Produk (X1) sebesar $-0,20$, artinya jika produk naik satu satuan, maka kepuasan pasien terhadap rehabilitasi medik fisioterapi Rumah Sakit Undata menurun. 
Peoni, M.

2. Koefisien regresi variabel Harga (X2) sebesar 0,107, artinya jika harga naik satu satuan, maka kepuasan pasien terhadap rehabilitasi medik fisioterapi Rumah Sakit Undata meningkat.

3. Koefisien regresi variabel Promosi (X3) sebesar -0,091, artinya jika promosi naik satu satuan, maka kepuasan pasien terhadap rehabilitasi medik fisioterapi Rumah Sakit Undata menurun.

4. Koefisien regresi variabel Tempat (X4) sebesar 0,243, artinya jika tempat naik satu satuan, maka kepuasan pasien terhadap rehabilitasi medik fisioterapi Rumah Sakit Undata meningkat.

5. Koefisien regresi variabel Orang (X5) sebesar 0,159, artinya jika orang naik satu satuan, maka kepuasan pasien terhadap rehabilitasi medik fisioterapi Rumah Sakit Undata meningkat.

6. Koefisien regresi variabel Bukti Fisik (X6) sebesar -0,043, artinya jika bukti fisik naik satu satuan, maka kepuasan pasien terhadap rehabilitasi medik fisioterapi Rumah Sakit Undata meningkat.

7. Koefisien regresi variabel Proses (X7) sebesar 0,541, artinya jika orang naik satu satuan, maka kepuasan pasien terhadap rehabilitasi medik fisioterapi Rumah Sakit Undata meningkat.

\section{Hasil Pengujian Hipotesis}

\section{Hasil Pengujian Hipotesis Secara Simultan (Uji F)}

Tahap selanjutnya adalah menguji signifikan hubungan atau uji $\mathrm{F}$ antara variabel penelitian yaitu bauran pemasaran $\left(\operatorname{Produk}\left(\mathrm{X}_{1}\right), \operatorname{Harga}\left(\mathrm{X}_{2}\right)\right.$, Promosi $\left(\mathrm{X}_{3}\right)$, Tempat $\left(\mathrm{X}_{4}\right), \operatorname{Orang}\left(\mathrm{X}_{5}\right)$, Bukti Fisik $\left(\mathrm{X}_{6}\right)$ dan Proses $\left(\mathrm{X}_{7}\right)$ ) terhadap kepuasan pasien( $(\mathrm{Y})$ dengan perhitungan menggunakan SPSS 16.0 dengan hasil sebagai berikut:

Tabel 3. Hasil Uji F(Simultan) ANOVA $^{b}$

\begin{tabular}{ll|r|r|r|r|r}
\hline \multicolumn{1}{c|}{ Model } & Sum of Squares & Df & Mean Square & F & \multicolumn{1}{c}{ Sig. } \\
\hline 1 & Regression & 22.182 & 7 & 3.169 & 19.881 & $.000^{\mathrm{a}}$ \\
Residual & 14.345 & 90 & .159 & & \\
Total & 36.527 & 97 & & & \\
\hline
\end{tabular}

Sumber: Data diolah Tahun 2018

Berdasarkan tabel di atas, diperoleh nilai sig F yaitu 0,000, artinya nilai tersebut lebih kecil jika dibandingkan dengan nilai yang diisyaratkan yaitu $\alpha 0,05$. Hal ini dapat dinyatakan bahwa secara serempak variabel dari Produk, Harga, Promosi, Tempat, Orang, Bukti Fisik, Proses berpengaruh signifikan terhadap kepuasan pasien rawat jalan rehabilitasi Medik Rumah Sakit Undata Palu.

\section{Hasil Pengujian Hipotesis Secara parsial (Uji t)}

Pengujian hipotesis secara parsial adalah untuk mengetahui apakah variabel produk, harga, promosi, tempat, orang, bukti fisik, dan proses secara positif dan signifikan terhadap kepuasan pasien rawat jalan rehabilitasi medik rumah sakit Undata Palu. Adapun hasil pengujiansecara parsial untuk setiapvariabel independen dapat dilihat dari penjelasan berikut:

1. Variabel Produk

Hasil pengujian rekapitulasi regresi linear berganda di atas, menunjukkan nilai signifikansi 0,799, artinya nilai tersebut lebih besar dari taraf signifikansi yang di syaratkan $\alpha 0,05$. Maka dapat disimpulkan bahwa secara parsial produk berpengaruh tidak signifikan terhadap kepuasan pasien rawat jalan rehabilitasi medik Rumah Sakit Undata Palu

2. Variabel Harga

Hasil pengujian rekapitulasi regresi linear berganda di atas, menunjukkan variabel harga memiliki nilai signifikansi 0,157 , artinya nilai tersebut lebih besar dari taraf signifikansi yang di syaratkan $\alpha$ 
0,05. Maka dapat disimpulkan bahwa secara parsial harga berpengaruh tidak signifikan terhadap kepuasan pasien rawat jalan rehabilitasi medik Rumah Sakit Undata Palu

3. Variabel Promosi

Hasil pengujian regresi linear berganda di atas, menunjukkan variabel promosi memiliki nilai signifikansi 0,253, artinya nilai tersebut lebih besar dari taraf signifikansi yang di syaratkan $\alpha 0,05$. Maka dapat disimpulkan bahwa secara parsial promosi berpengaruh tidak signifikan terhadap kepuasan pasien rawat jalan rehabilitasi medik Rumah Sakit Undata Palu

4. Variabel Tempat

Hasil pengujian rekapitulasi regresi linear berganda di atas, menunjukkan variabel tempat memiliki nilai signifikansi 0,008 , artinya nilai tersebut lebih kecil dari taraf signifikansi yang di syaratkan $\alpha$ 0,05. Maka dapat disimpulkan bahwa secara parsial tempat berpengaruh signifikan terhadap kepuasan pasien rawat jalan rehabilitasi medik Rumah Sakit Undata Palu

\section{Variabel Orang}

Hasil pengujian regresi linear berganda di atas, menunjukkan variabel orang memiliki nilai signifikansi 0,120, artinya nilai tersebut lebih besar dari taraf signifikansi yang di syaratkan $\alpha 0,05$.

Maka dapat disimpulkan bahwa secara parsial orang berpengaruh tidak signifikan terhadap kepuasan pasien rawat jalan rehabilitasi medik Rumah Sakit Undata Palu

6. Variabel Bukti fisik

Hasil pengujian rekapitulasi regresi linear berganda di atas, menunjukkan variabel orang memiliki nilai signifikansi 0,503 , artinya nilai tersebut lebih besar dari taraf signifikansi yang di syaratkan $\alpha$ 0,05. maka dapat disimpulkan bahwa secara parsial orang berpengaruh tidak signifikan terhadap kepuasan pasien rawat jalan rehabilitasi medik Rumah Sakit Undata Palu

7. variabel Proses

Hasil pengujian regresi linear berganda di atas, menunjukkan variabel proses memiliki nilai signifikansi 0,000, artinya nilai tersebut lebih kecil dari taraf signifikansi yang di syaratkan $\alpha 0,05$. Maka dapat disimpulkan bahwa secara parsial proses berpengaruh tidak signifikan terhadap kepuasan pasien rawat jalan rehabilitasi medik Rumah Sakit Undata Palu

\section{Pembahasan atau Hasil Analisis \\ Produk}

salah satu yang akan langsung mempengaruhi apakah suatu pemasaran itu akan berhasil atau gagal adalah produk. Dimana produk yang baik serta sesuai dengan keinginan konsumen akan menghasilkan kepuasan konsumen yang berimbas pada suksesnya pemasaran sebuah perusahaan. Indikator produk dalam penelitian ini ketersediaan kamar, ketersediaan fasilitas kesehatan, ketersediaan ruang konsultasi.

Berdasarkan hasil penelitian membuktikan bahwa variabel produk tidak berpengaruh secara signifikan terhadap kepuasan pasien di rehabilitasi medik Rumah Sakit Undata Palu. Hal ini bisa terjadi karena image Rumah Sakit Undata Palu baik di masyarakat, sehingga pasien sudah mempunyai keyakinan bahwa Rehabilitasi Medik Rumah Sakit Undata Palu akan memberikan pelayanan yang sesuai dengan yang di butuhkan pasien.

\section{Harga}

Berdasarkan hasil penelitian yang dilakukan membuktikan bahwa variabel harga tidak berpengaruh secara signifkan terhadap kepuasan pasien rehabilitasi medik Rumah Sakit Undata Palu. Penelitian yang dilakukan pada pasien rehabilitasi medik Rumah Sakit Undata Palu bahwa indikator kesesuaian harga dengan kulalitas produk dan jasa yang di berikan tidak cukup berpengaruh signifikan terhadap kepuasan pasien rehabilitasi medik Rumah Sakit Undata Palu.

Indikator selanjutnya yaitu Potongan harga, indikator ini juga berpengaruh tidak signifikan terhadap kepuasan pasien rehabilitasi medik Rumah Sakit Undata Palu. Hal ini terjadi karena biaya 
Peoni, M.

berobat pasien sudah di tanggung oleh pemerintah melalui program BPJS Kesehatan sehingga pasien tidak mempertimbangkan lebih dalam lagi mengenai harga sebelum berobat.

\section{Promosi}

promosi diartikan sebagai serangkaian anggapan dan kesan konsumen tentang kegiatan-kegiatan yang dilakukan pada rehabilitasi medik Rumah Sakit Undata Palu dalam memperkenalkan produknya sehingga dapat dikenal dengan mudah. Indikator dalam variabel prosmosi adalah Informasi sekitar, Informasi melalui website resmi dan iklan media cetak

Berdasarkan hasil penelitian ini, indikator-indikator yang digunakan untuk mengukur promosi rehabilitasi medik Rumah Sakit Undata Palu tidak berpengaruh secara signifikan terhadap kepuasan pasien yang menggunakan jasa rehabilitasi medik Rumah Sakit Undata Palu. Hal ini menunjukkan bahwa promosi yang dilakukan oleh rehabilitasi medik tidak mempengaruhi kepuasan pasien dalam menggunakan layanan rehabilitasi medik. Salah satu faktornya adalah kegiatan promosi dan penyampaian informasi melalui website resmi tidak terlalu efektif dan tidak bisa dirasakan langsung oleh pasien yang memilih menggunakan jasa rehabilitasi medik Rumah Sakit Undata Palu.

\section{Tempat}

Lokasi penelitian ini diartikan sebagai tempat pelayanan yang digunakan dalam memasok produk kepada konsumen yang dituju. Lokasi yang dimaksud adalah dimana rehabilitasi medik beroperasi. Indikator dalam variabel tempat adalah mudah di akses, dekat dengan ruangan lain dan berada dalam kota.

Berdasarkan hasil pengujian statistik menunjukkan bahwa variabel tempat berpengaruh secara signifikan terhadap kepuasan Pasien menggunakan jasa rehabilitasi medik Rumah Sakit Undata Palu. Hal ini menunjukkan bahwa tempat yang dimiliki oleh rehabilitasi medik Rumah Sakit Undata Palu sudah cukup baik yakni memiliki lokasi yang dekat dengan ruangan lain, mudah diakses dan berada di dalam kota sehingga dapat mempengaruhi kepuasan pasien dalam menggunakan jasa rehabilitasi medik Rumah Sakit Undata Palu.

\section{Orang}

Sumber daya manusia diartikan sebagai serangkaian anggapan dan kesan-kesan pasien tentang perawat-perawat yang terlibat langsung dalam menjalankan aktivitas pada rehabilitasi medik Rumah Sakit Undata Palu. Adapun indikator dalam variabel orang adalah kemampuan dalam pelayanan, kemampuan dalam memberi informasi serta sopan dan ramah dalam pelayanan

Berdasarkan hasil pengujian statistik menunjukkan bahwa variabel orang tidak berpengaruh secara signifikan terhadap kepuasan pasien. Hal ini menunjukkan bahwa perawat dalam memberikan layanan rehabilitasi medik masih kurang optimal. Hal ini bisa terjadi karena penanganan rehabilitasi medik harus di bantu dengan alat yang mendukung, agar penanganan rehabilitasi medik dapat optimal dan pasien merasa puas.

\section{Bukti Fisik}

Bukti fisik adalah sebagai serangkaian anggapan tentang segala hal yang secara langsung dilhat oleh pasien dalam menggunakan jasa rehabilitasi medik Rumah Sakit Undata Palu. Adapun indikator dalam variabel bukti fisik adalah sarana parkir, kebersihan ruangan dan keseragaman pakaian perawat.Berdasarkan hasil pengujian statistik menunjukkan bahwa variabel Bukti Fisik tidak berpengaruh secara signifikan terhadap kepuasan pasien. Hal ini menunjukkan bahwa indikator yang di ukur dalam variabel bukti fisik tidak cukup berpengaruh secara signifikan terhadap kepuasan pasien dalam menggunakan jasa rehabilitasi medik Rumah Sakit Undata Palu. Salah satu indikatornya yaitu sarana parkir yang luas namun lahan parkir tersebut tidak diatur secara rapi sehingga menyebabkan terganggunya arus keluar masuk yang ada dalam lingkungan Rumah Sakit. 


\section{Proses}

Proses diartikan sebagai serangkaian anggapan dan kesan-kesan pasien tentang segala bentuk upaya Perawat dalam melakukan penanganan terhadap pasien. Adapun indikator dalam variabel proses yaitu kecepatan proses pelayanan administrasi, kecepatan dalam menangani pasien dan kecepatan dalam pelayanan.

Berdasarkan hasil pengujian statistik menunjukkan bahwa variabel proses berpengaruh signifikan terhadap struktur kepuasan pasien menggunakan jasa rehabilitasi medik Rumah Sakit Undata Palu. Hal ini menunjukkan bahwa Proses yang diterapkan oleh rehabilitasi medik Rumah Sakit Undata Palu sudah cukup baik yakni kecepatan dalam proses pelayanan administrasi dan ketepatan dalam pelayanan pasien sehingga dapat mempengaruhi kepuasan pasien dalam menggunakan jasa rehabilitasi medik Rumah Sakit Undata Palu.

\section{PENUTUP}

\section{Kesimpulan}

Berdasarkan hasil penelitian yang telah dijelaskan, maka diperoleh kesimpulan mengenai Bauran Pemasaran Jasa terhadap Kepuasan Pasien Rawat Jalan Rehabilitasi Medik Rumah Sakit Undata Palu sebagai berikut

1. Bauran pemasaran jasa yang terdiri dari produk, harga, promosi, tempat, orang, bukti fisik dan Proses secara simultan berpengaruh signifikan terhadap kepuasan pasien rehabilitasi medik Rumah Sakit Undata Palu.

2. Dimensi produk secara parsial berpengaruh tidak signifikan terhadap kepuasan pasien rehabilitasi medik Rumah Sakit Undata Palu

3. Dimensi harga secara parsial berpengaruh tidak signifikan terhadap kepuasan pasien rehabilitasi medik Rumah Sakit Undata Palu

4. Dimensi promosi secara parsial berpengaruh tidak signifikan terhadap kepuasan pasien rehabilitasi medik Rumah Sakit Undata Palu

5. Dimensi tempat secara parsial berpengaruh signifikan terhadap kepuasan pasien rehabilitasi medik Rumah Sakit Undata Palu

6. Dimensi orang secara parsial berpengaruh tidak signifikan terhadap kepuasan pasien rehabilitasi medik Rumah Sakit Undata Palu

7. Dimensi bukti fisik secara parsial berpengaruh tidak signifikan terhadap kepuasan pasien rehabilitasi medik Rumah Sakit Undata Palu

8. Dimensi proses secara parsial berpengaruh signifikan terhadap kepuasan pasien rehabilitasi medik Rumah Sakit Undata Palu

\section{Saran}

1. Hasil analisis menunjukkan bahwa variabel tempat mempunyai pengaruh yang dominan terhadap proses kepuasan pasien dibandingkan dengan variabel lainnya, oleh karena itu pihak Rehabilitasi Medik disarankan agar lebih mengembangkan tempat layanan yang disediakan

2. Hasil analisis menunjukkan bahwa variabel produk mempunyai pengaruh yang sedikit terhadap kepuasan pasien rehabilitasi medik, oleh karena itu pihak Rumah Sakit Undata Palu lebih mengembangkan produk barang dan jasa yang ada di Rehabilitasi Medik agar kepuasan pasien dapat dirasakan manfaatnya.

3. Pihak Rumah Sakit Undata Palu diharapkan terus memperbaharui lahan parkir yang lebih rapi agar arus keluar masuk kendaraan dalam lingkungan rumah sakit tidak terhambat

4. Rehabilitasi Medik RS Undata sudah memberikan pelayanan yang cukup baik kepada pasien, namun pelayanan tersebut harus lebih ditingkatkan lagi dengan cara melengkapi alat-alat 
Peoni, M.

terapi dan dokter selalu mendengarkan keluhan dari pasiennya agar pasien akan merasa puas dan nyaman untuk berobat di Rehabilitasi Medik RS Undata Palu.

5. Rehabilitasi medik RS Undata Palu harus lebih memperhatikan biaya perawatan yang akan di tawarkan kepada pasien, karena sebagian besar pasien yang berobat adalah pasien yang berlatar belakang ekonomi menengah ke bawah.

6. Rehabilitasi Medik RS Undata Palu harus terus meningkatkan kemampuan dan disiplin dokter, perawat dan pegawai administrasinya serta meingkatkan mutu pelayanan agar terwujudnya suatu pelayanan yang profesional

7. Bagi peneliti selanjutnya, diharapkan penelitian ini dapat dijadikan bahan acuan dan perbandingan dalam melakukan penelitian serupa di masa yang akan datang, khususnya tentang bauan pemasan jasa dan pengaruhnya terhadap kepuasan konsumen.

\section{REFERNSI}

Adam, Rosida, 2010. Manajemen pemasaran,Lembagga Pengkajian Pembaharuan Hukum dan Kebijakan Publik (LP2HKP), Palu.

Ghozali, Imam, 2013. Aplikasi Analisis Multivariat Dengan Program IBM SPSS 21, Edisi7.

Universitas Diponegoro: Semarang.

Sugiyono, (2014) Metode Penelitian Bisnis (Pendekatan. Kuantitatif, Kualitatif, dan R\&D), Cetakan Ke-18. Bandung: Alfabeta.

Sunyoto, Danang. (2013). Metodologi Penelitian Akuntansi., Bandung: PT Refika Aditama

Tjiptono, Fandy (2014). Pemsaran Jasa - Prinsip, Penerapan, dan Penelitian. Edisi I. Yogyakarta: Andi.

Zahara dan Rombe (2017). "The Effect of Tourism Product, Promotion, and Individual Charactersitics on Tourists' Decision”. International Journal of Economic Research Vol 14, No. 4, $168-169$ 